\title{
Students' motivation to attend group guidance based on gender and ethnic
}

\author{
Rezki Hariko ${ }^{1}$, Herman Nirwana ${ }^{1}$, Rima Pratiwi Fadli ${ }^{2}$, Ifdil Ifdil ${ }^{1}$, Hastiani Hastiani ${ }^{3}$, \\ \& Rahmi Dwi Febriani ${ }^{1}$ \\ ${ }^{1}$ Universitas Negeri Padang, Indonesia \\ ${ }^{2}$ Indonesian Institute for Counseling, Education and Therapy, Indonesia, \\ ${ }^{3}$ IKIP PGRI Pontianak, Indonesia.
}

*Corresponding author, e-mail: hariko.r@fip.unp.ac.id

\begin{abstract}
Although group guidance is believed to be an effective and efficient service to facilitate the development of positive aspects and prevention of negative aspects of students, the frequency of its use for students is not optimal. This study aims to analyze student motivation to follow group guidance and differences in their motivation based on gender and ethnicity. The study used a comparative descriptive method. A total of 690 samples were involved in write-paper-and-pencil questionnaires, namely the students' motivation scale to attend group guidance, which was designed based on the Likert Scale model. We analyzed data using descriptive statistics and different test analysis using independent samples t-test and Bayesian method by applying JASP software. Analysis results showed that most students have the prime motivation to follow group guidance and there are significant differences in student motivation to follow group guidance based on gender, but in terms of ethnicity did not show any significant differences. School counselor can implement the findings of this study in determining group members in group guidance services.
\end{abstract}

Keywords: Group guidance, Motivation, Gender, Ethnic.

How to Cite: Hariko, R., Nirwana, H., Fadli, R.P., Ifdil, I., Hastiani, H., \& Febriani, R.D. (2021). Students' motivation to attend group guidance based on gender and ethnic. International Journal of Research in Counseling and Education, 5 (1): pp. 85-96, DOI:https://doi.org/10.24036/00412za0002

\section{Introduction}

Guidance and counseling is a professional activity that involves a relationship between a counselor and an individual or group of individuals (Hariko, 2016, 2017; Ifdil et al., 2020). It is an integral component in education whose existence is increasingly (Daharnis et al., 2014; Hariko \& Ifdil, 2017) as an effort to develop oneself of, solve problems of and other specific goals of the individual (Hariko, 2016, 2017). One type of activity in the guidance and counseling service is referred to as group guidance, which it is a type of service provided by counselors in a group format to several individuals (students) to discuss factual topics by utilizing group dynamics based on specific theories and approaches. Today, the term more global psycho-educational group is used instead of the term group guidance (Neukrug, 2011). This shift is in response to negative or mistaken connotations of the term group guidance which is misinterpreted as activities that are highly advice-oriented and have moral demands (Gladding, 2003). In contrast to global trends, implementing guidance and counseling in Indonesia continues to use the term group guidance (Hariko, 2020, 2021). This article uses the term group guidance by citing references that use both terms and other congruent terms in the explanation.

The focus of group guidance activities in guidance and counseling is different compared to other group activities. Group guidance is the activity of providing or delivering information, discussing topics or materials, or discussing values by utilizing group dynamics (Brown, 2004; Gladding, 2003; Prayitno, 2017). Group guidance focuses on developing members' cognitive, affective, and behavioral skills through a series of structured procedures in and throughout the meeting (Corey, Corey, \& Corey, 2014). Group guidance carries educational, development and prevention goals (ASGW, 2000). Group guidance aims to develop social skills, especially communication skills, and specifically encourage the development of more effective and responsible 
feelings, thoughts, perceptions and attitudes (Prayitno, 2017). From the preventive side, group guidance is a strategic activity to prevent individuals from exposure to various potential problems. Through discussion of specific topics, students are expected to be prevented from the influence of a variety of personal and social disorders (Gladding, 2003), and able to face crises and developmental problems (Brown, 2004).

Various studies related to group guidance have been conducted extensively and involve middle school students as group members. By integrating various techniques and approaches, it has proven group guidance to be effective in developing students' positive potentials and protecting them from negative developments. Recent studies provide evidence of the effectiveness of group guidance as forum for positive development aspects, for example, career direction planning, social interactions with peers and student disciplinary attitudes (misal, Nengsih, 2019; Normanita, Kurniawan, \& Nusantoro, 2018; Putra, 2019). The results also prove that group guidance activities are very effective to overcome learning difficulties and increase students' understanding of bullying behavior (for example, Astuti, 2019; Fatmala \& Nursalim, 2019). Most of the existing research uses experimental methods or other types involving a tiny sample. They applied the study to samples recruited based on the specific objectives of the study and paid less attention to the motivational conditions of students. Ironically, there is very little research and recent publications that examine student motivation following group guidance.

Student's motivation to attend group guidance is an important psychological aspect that counselors need to consider before planning activities. Motivation is defined as an impulse arising from internal and/or external stimulation so that someone wishes to change certain behaviors or activities to be better than the previous situation (Uno, 2007). Motivation determines the direction, resilience and persistence of individuals in carrying out actions (Moreno, 2010; Nolen-Hoeksema et al., 2014).

Some fundamental theories that discuss motivation emphasize definitions in different, but interrelated aspects. These theories view motivation as behavior directed at goals that are provoked and defended by individual expectations regarding expected outcomes of actions and self-confidence to do so, products of expectations to achieve the goals and values of goals, and behaviors directed by needs (Moreno, 2010; Schunk., 2012; Schunk et al., 2012; Schunk \& DiBenedetto, 2020). Summarizing a number of theoretical views, motivation in this study is defined as encouragement in students to follow group guidance as indicated by the presence of desire and interest, encouragement and needs, as well as expectations for the results of group guidance activities.

The current research aims to describe the picture of students' motivation to follow group guidance and examine differences in student motivation to follow group guidance based on both gender and ethnicity. The hypothesis put forward in this study is that there are significant differences in students' motivation to follow group guidance based on both gender and etnicity.

\section{Method}

The study used a comparative descriptive method. A total of 690 students obtained using cluster random sampling technique $(52.75 \%$ female, $\mathrm{M}$ age $=14.02)$ Junior High School in the Padang City $(13.58 \% 7$ th grade, $39.27 \%$ 8th grade, $47.15 \%$ 9th grade) completing 26 items of paper-and-pencil questionnaire to measure students' motivation to attend group guidance. Data collection is done on the willingness of students as respondents. Administering the questionnaire was conducted by researchers collaborating with school counselors for two months. Description of student motivation is obtained based on data analysis using descriptive statistical formulas. Student motivation levels are categorized into four groups based on the normal distribution model. Analysis of differences in student motivation based on gender was carried out using the formula of independent samples test (t-test) and Bayesian method. Data were analyzed using JASP (Jeffrey's Amazing Statistics Program) version 0.12.

\section{Result}

Measurement of student motivation to follow group guidance on research, including: the desire of students to follow group guidance, encouragement of students to follow group guidance, and student expectations of the results of group guidance activities. The categorization of students' motivation levels is grouped into four class intervals - veryhigh, high, low and very low - based on the estimated size of the population standard deviation unit $(\sigma)$, theoretical mean $\left(\mu_{\mathrm{t}}\right)$, minimum score $\left(X_{\min }\right)$ and maximum score $\left(X_{\max }\right)$. A description of the level of student motivation based on its categorization is presented in Table 1 below. 
Table 1. Description of Student Motivation to Involved Group Guidance based on Gender

\begin{tabular}{lcc}
\hline & \multicolumn{3}{c}{ Total Score } & \\
\hline Valid & M & W \\
Missing & 326 & 364 \\
Mean & 0 & 0 \\
Std. Deviation & 92.936 & 100.310 \\
Minimum & 16.771 & 15.770 \\
Maximum & 37.000 & 47.000 \\
\hline
\end{tabular}

Table 2. Description of Student Motivation to Involved Group Guidance based on Ethnicity

\begin{tabular}{lrrrrrrrrrr}
\hline & \multicolumn{10}{c}{ Students's Motivation } \\
\cline { 2 - 11 } & \multicolumn{1}{c}{ A } & B & \multicolumn{1}{c}{ C } & \multicolumn{1}{c}{ D } & E & F & G & H & \multicolumn{1}{c}{ I } \\
\hline Valid & 579 & 3 & & 9 & 28 & 41 & 1 & 11 & 1 & 17 \\
Missing & 0 & 0 & 0 & 0 & 0 & 0 & 0 & 0 & 0 \\
Mean & 96.805 & 104.667 & 94.556 & 95.321 & 102.268 & 105.000 & 89.909 & 102.000 & 90.412 \\
Std. Deviation & 16.715 & 17.243 & 14.909 & 15.031 & 16.658 & NaN & 12.062 & NaN & 18.871 \\
Minimum & 37.000 & 86.000 & 72.000 & 70.000 & 65.000 & 105.000 & 75.000 & 102.000 & 49.000 \\
Maximum & 130.000 & 120.000 & 118.000 & 120.000 & 127.000 & 105.000 & 116.000 & 102.000 & 124.000 \\
\hline
\end{tabular}

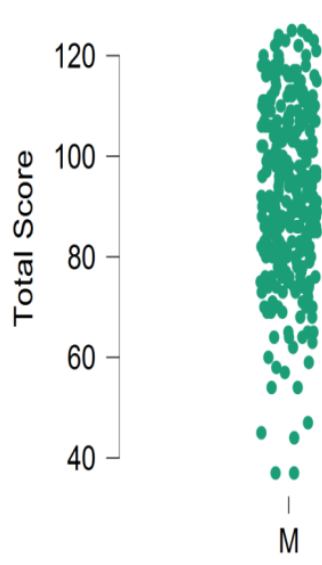

Gender

Figure 1. Student's Motivation Based Gender

Information:

$\begin{array}{ll}\text { A } & \text { : Minang } \\ \text { D } & \text { : Jawa } \\ \text { G } & \text { : Nias }\end{array}$
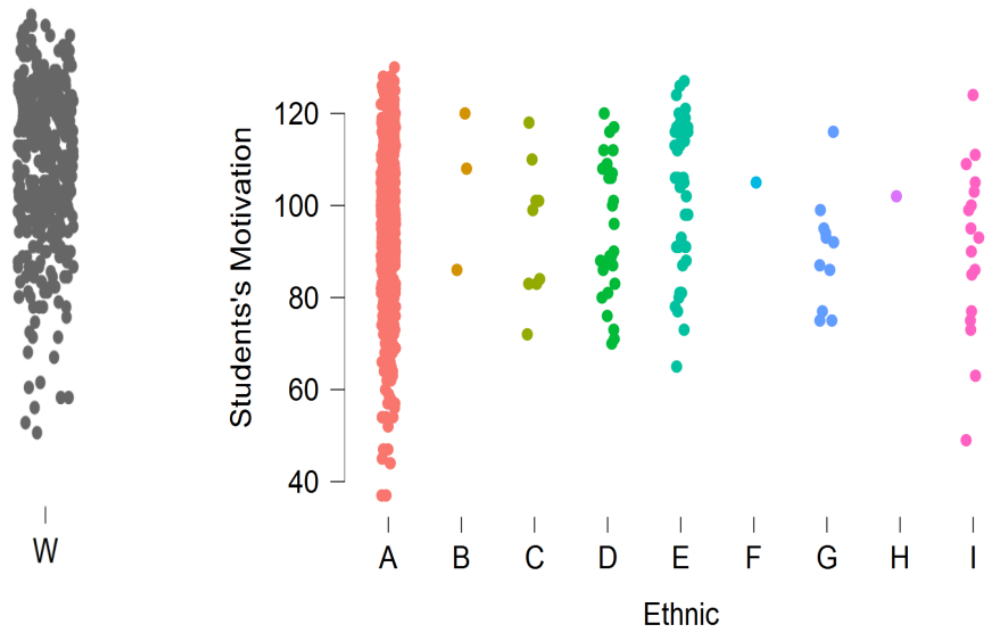

Figure 2. Student's Motivation Based Ethnic

Based on tables 1 and 2 it was found that the study sample in terms of gender, mean female scores were higher than average male scores. Furthermore, when viewed from ethnicity, it shows that the average ethnic Aceh score is higher than the average score of other ethnicities. The distribution of research samples can be seen in Figure 1 and Figure 2. Based on Figure 1, it can be seen that student motivation based on gender has an average range of data distribution that is almost the same, this is also seen in Table 1. Furthermore, based on Figure 2, it is known that the ethnic group that has a high data distribution is the Minang ethnic group and the least namely Betawi ethnicity. 
Tabel 3. Description of Student Motivation to Involved Group Guidance $(\mathrm{N}=690)$

\begin{tabular}{|c|c|c|c|c|c|c|c|c|c|c|}
\hline \multirow{3}{*}{ Aspect } & \multirow{3}{*}{$\underset{\text { Mean }}{\sigma}$} & \multirow{3}{*}{$\boldsymbol{\mu}_{t}$} & \multicolumn{8}{|c|}{ Category } \\
\hline & & & \multicolumn{2}{|c|}{ Very High } & \multicolumn{2}{|c|}{ High } & \multicolumn{2}{|c|}{ Low } & \multicolumn{2}{|c|}{ Very Low } \\
\hline & & & f & $\%$ & f & $\%$ & f & $\%$ & f & $\%$ \\
\hline $\begin{array}{l}\text { The desire of students } \\
\text { to follow group } \\
\text { guidance }\end{array}$ & 7 & 21 & 291 & 42.2 & 302 & 43.8 & 88 & 12.7 & 9 & 1.3 \\
\hline $\begin{array}{l}\text { Encouragement of } \\
\text { students to follow } \\
\text { group guidance }\end{array}$ & 9 & 27 & 215 & 31.2 & 328 & 47.5 & 128 & 18.6 & 19 & 2.7 \\
\hline $\begin{array}{l}\text { Student expectations } \\
\text { of the results of group } \\
\text { guidance activities }\end{array}$ & 10 & 30 & 365 & 52.9 & 260 & 37.7 & 55 & 7.9 & 10 & 1.5 \\
\hline Total & 26 & 78 & 269 & 39.0 & 334 & 48.4 & 80 & 11.6 & 7 & 1.0 \\
\hline
\end{tabular}

In Table 3 and figure 3, figure 4 and figure 5 are illustrated by the data of student motivation attending group guidance on the three aspects reviewed. In the first aspect - thedesire to follow group guidance - $86.0 \%$ of students have high and very high motivation and only $14.0 \%$ of students have low and very low motivation. In the second aspect - encouragementto follow group guidance $-78.7 \%$ of students have high and very high motivation and only $21.3 \%$ of students have low and very low motivation. In the third aspect - expectationsof group guidance activities - 90.6\% of students have high and very high motivation and only $9.4 \%$ of students have low and very low motivation. Then, based on overall data, $87.4 \%$ of students have high and very high motivation and only $12.6 \%$ of students have low and very low motivation. In conclusion, most students are motivated to attend group guidance.

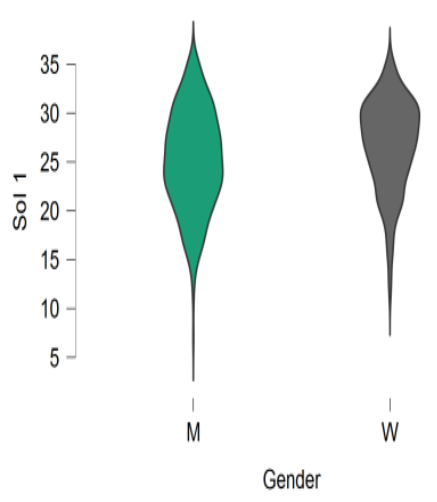

Figure 3. SoI 1

Information: SoI = Score of Indicator

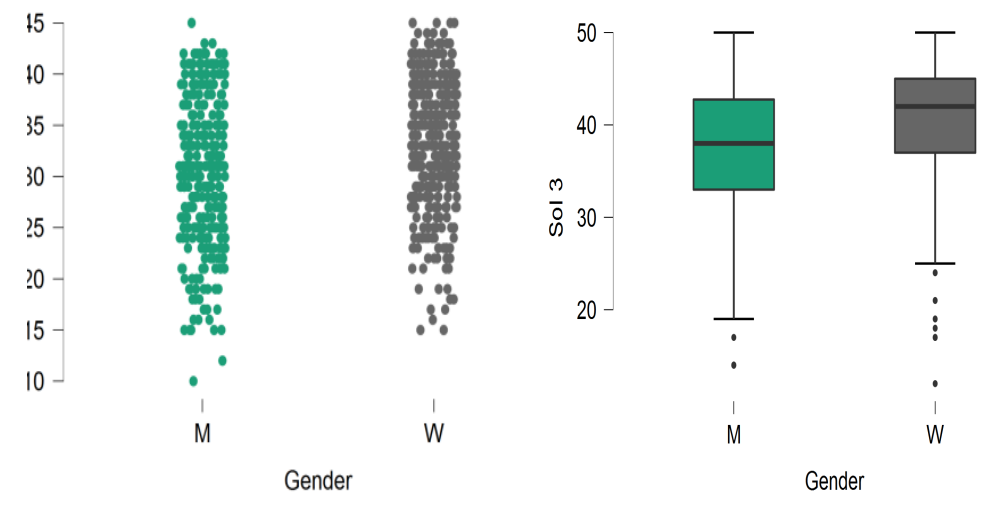

Figure 4. SoI 2

Figure 5. Sol 3

Table 4. Descriptives - Students's Motivation

\begin{tabular}{rrrrrrr}
\hline & & & & & \multicolumn{2}{c}{ 95\% Credible Interval } \\
\cline { 6 - 7 } Gender & Ethnic & \multicolumn{1}{c}{ Mean } & SD & N & Lower & Upper \\
\hline M & A & 92.517 & 16.910 & 269 & 90.487 & 94.547 \\
& B & 104.667 & 17.243 & 3 & 61.832 & 147.502 \\
C & 94.667 & 14.067 & 6 & 79.905 & 109.429 \\
& D & 91.167 & 17.678 & 12 & 79.935 & 102.399 \\
E & 98.895 & 16.799 & 19 & 90.798 & 106.992 \\
F & 105.000 & & 1 & & \\
& G & 90.600 & 17.068 & 5 & 69.408 & 111.792 \\
& I & 90.636 & 14.459 & 11 & 80.923 & 100.350
\end{tabular}




\begin{tabular}{rrrrrrr}
\hline & & & & & \multicolumn{2}{c}{ 95\% Credible Interval } \\
\cline { 6 - 7 } Gender & Ethnic & \multicolumn{1}{c}{ Mean } & \multicolumn{1}{l}{ SD } & \multicolumn{1}{c}{ N } & \multicolumn{1}{c}{ Lower } & Upper \\
\hline W & A & 100.526 & 15.643 & 310 & 98.778 & 102.274 \\
& C & 94.333 & 19.858 & 3 & 45.004 & 143.663 \\
D & 98.438 & 12.383 & 16 & 91.839 & 105.036 \\
E & 105.182 & 16.355 & 22 & 97.930 & 112.433 \\
G & 89.333 & 7.554 & 6 & 81.406 & 97.261 \\
H & 102.000 & & 1 & & \\
I & 90.000 & 26.855 & 6 & 61.817 & 118.183 \\
\hline
\end{tabular}

Note. Some combinations of factors are not observed and hence omitted ( 3 out of 18 combinations are unobserved).

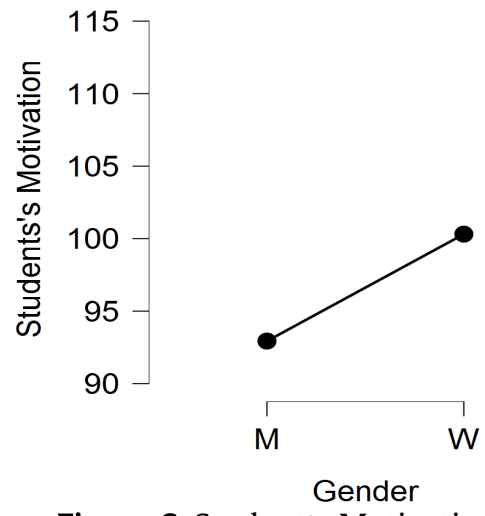

Figure 6. Student's Motivation Based Gender

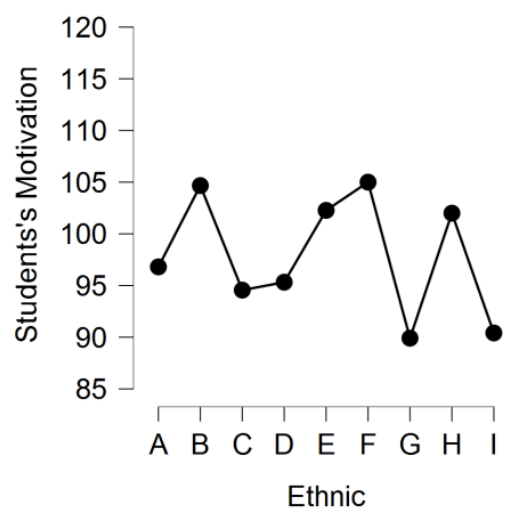

Figure 7. Student's Motivation Based Ethnic

Information:

$\begin{array}{lllll}\text { Information: } & & & \\ \text { A : Minang } & \text { B } & \text { : Bugis } & \text { C } & \text { : Batak } \\ \text { D : Jawa } & \text { E } & \text { : Melayu } & \text { F } & \text { : Aceh } \\ \text { G : Nias } & \text { H } & \text { : Betawi } & \text { I } & \text { : Others }\end{array}$

In Table 4 the group statistics display on the motivation of students attending group guidance is presented. The mean score of men's motivation scores is lower than that of women $(92.69<100.31)$ which means that the motivation of male students to follow group guidance is lower than that of women. The standard deviation values indicate that the data distribution of men is greater than that of women $(17.47>15.77)$. The standard error value is small for both genders, reflecting the high level of accuracy of sample data with the population. When viewed from ethnicity and gender it was found that women from the Melayu ethnic group had an average score higher than other ethnic women (figure 6 and figure 7). As for the male sex of the ethnic Aceh, the average score is higher than other ethnic groups in the male gender.

Testing differences in student motivation to take group guidance based on gender using an independent samples test (t-test) using the Statistical Package for the Social Sciences (SPSS) program. An overview of group statistical data and differences in the test results is presented in Table 3 and Table 4 . The next test examines the significance level of students' motivation differences by gender. In Table 5 it presents the following data on the results of testing differences in student motivation by gender using an independent samples test ( $t$ test).

Table 5. Data Testing the Difference in Student Motivation Using t-Tests

\begin{tabular}{|c|c|c|c|c|c|c|c|c|c|c|}
\hline \multirow{3}{*}{ Variable } & \multirow{3}{*}{ Asumsi Varian } & \multicolumn{3}{|c|}{$\begin{array}{c}\text { Levene's Test } \\
\text { for Equality of } \\
\text { Variances }\end{array}$} & \multicolumn{4}{|c|}{ t-test for Equality of Means } & \multirow{2}{*}{\multicolumn{2}{|c|}{$\begin{array}{l}\text { 95\% Confidence } \\
\text { Interval of the } \\
\text { Difference }\end{array}$}} \\
\hline & & \multirow[t]{2}{*}{$\mathrm{F}$} & \multirow[t]{2}{*}{ Sig. } & \multirow[t]{2}{*}{$\mathrm{t}$} & \multirow[t]{2}{*}{ df } & \multirow{2}{*}{$\begin{array}{l}\text { Sig. } \\
(2- \\
\text { tailed })\end{array}$} & \multirow[t]{2}{*}{$\begin{array}{l}\text { Mean } \\
\text { Diff. }\end{array}$} & \multirow[t]{2}{*}{$\begin{array}{l}\text { Std. } \\
\text { Error } \\
\text { Diff. }\end{array}$} & & \\
\hline & & & & & & & & & Lower & Upper \\
\hline $\begin{array}{l}\text { Student } \\
\text { Motivation to }\end{array}$ & $\begin{array}{l}\text { Equal variances } \\
\text { assumed }\end{array}$ & 1.83 & .18 & -6.02 & 688.00 & .00 & -7.61 & 1.27 & -10.09 & -5.13 \\
\hline $\begin{array}{l}\text { Involved } \\
\text { Group } \\
\text { Guidance }\end{array}$ & $\begin{array}{l}\text { Equal variances } \\
\text { not assumed }\end{array}$ & & & -5.99 & 658.47 & .00 & -7.61 & 1.27 & -10.11 & -5.12 \\
\hline
\end{tabular}


Table 5 presents Levene's test data (homogeneity test) and t test. The Levene's test shows the value of $\mathrm{F}$ is 1.83 with a significance of $0.18(>0.05)$ which indicates that the data variant is different so that the interpretation of the value of $t$ test refers to the line of equal variances not assumed. It is known that the value of $t$ is -5.99 with a significance of $0.00(<0.05)$ which means that there is a significant difference between students' motivation to attend group guidance based on gender. Final conclusion, there are differences in student motivation to follow group guidance where the motivation of men is lower than that of women, the distribution of research data is small, and the accuracy of sample data against high populations.

Tabel 6. Model Comparison

\begin{tabular}{lcrrrr}
\hline \multicolumn{1}{c}{ Models } & $\mathrm{P}(\mathbf{M})$ & $\mathrm{P}(\mathrm{M} \mid \mathrm{data})$ & \multicolumn{1}{c}{ BF $\mathbf{M}$} & \multicolumn{1}{c}{ BF 10 } & \multicolumn{1}{c}{ error \% } \\
\hline Gender & 0.200 & 0.805 & 16.479 & 1.000 & \\
Gender + Ethnic & 0.200 & 0.177 & 0.858 & 0.220 & 1.426 \\
Gender + Ethnic + Gender $*$ Ethnic & 0.200 & 0.019 & 0.076 & 0.023 & 1.464 \\
Null model & 0.200 & $4.069 \mathrm{e}-7$ & $1.627 \mathrm{e}-6$ & $5.056 \mathrm{e}-7$ & $8.402 \mathrm{e}-11$ \\
Ethnic & 0.200 & $1.002 \mathrm{e}-7$ & $4.007 \mathrm{e}-7$ & $1.245 \mathrm{e}-7$ & $6.449 \mathrm{e}-5$ \\
\hline
\end{tabular}

Table 6 results are obtained through a comparison of models in the Bayesian Method. The BF10 value obtained is H1 per H0. Bayesian Factor calculation results use Jeffrey's Scale to see how strong the calculation results obtained. The Bayesian calculation used is H1, several times greater or more likely than H0. Based on the Bayesian Factor values for the Gender model 1 was obtained which showed anecdotal evidence for H1 (supporting table 3). The Gender + Ethnic model has a bayesian factor 0.22 which indicates a range of $0.1-0.3$ (moderate evidence for H0. Furthermore, the interaction of Gender + Ethnic with Gender + Ethnic shows a bayesian factor value of 0.023 (within the range of 0.01-0.03) meaning that very strong evidence. Based on Table 5 and Table 6, it shows that in terms of gender, students' motivation to follow group guidance where there are significant differences between men and women (figure 8 and figure 10), then in terms of ethnicity there is no difference where the interaction results show very strong evidence for H0 (figure 9 and figure 10). It can be concluded that in carrying out group guidance, counselors / counseling teachers must pay attention to the gender composition in the group.

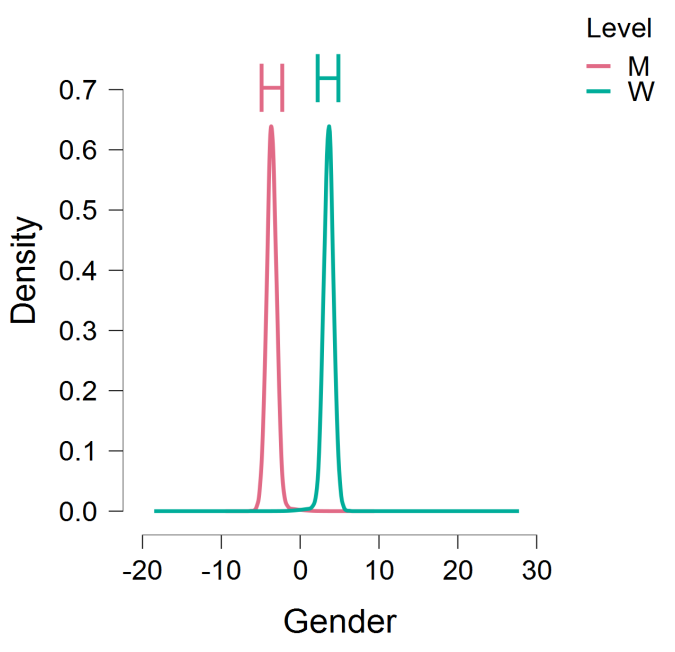

Figure 8. Gender

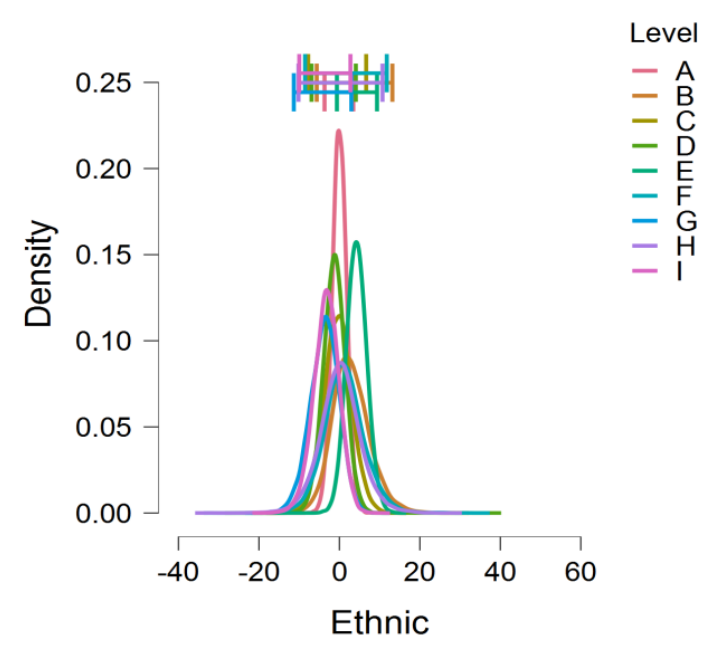

Figure 9. Ethnic 


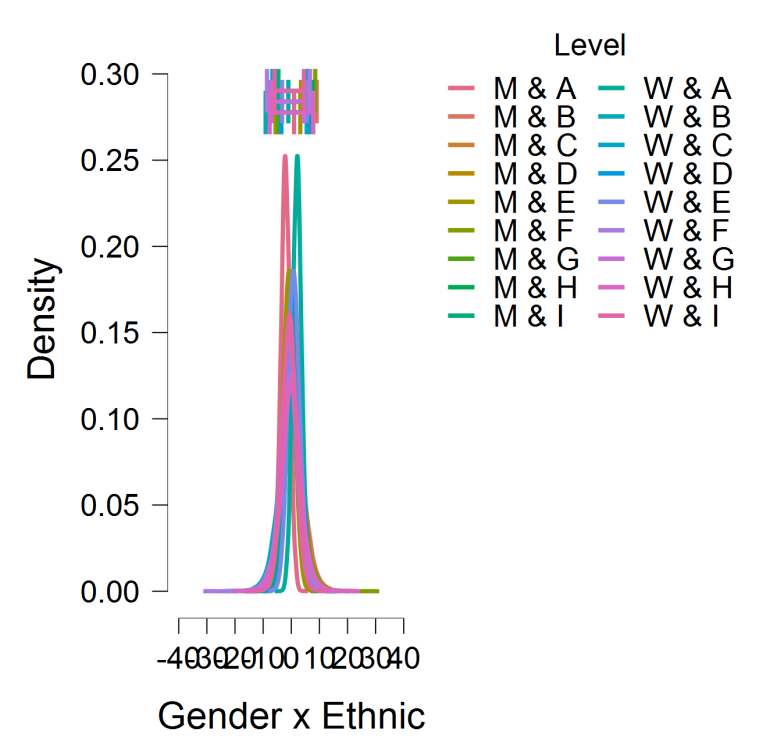

Figure 10. Gender * Ethnic

\section{Discussion}

Group guidance is a very effective service to facilitate students in understanding their own potential and circumstances and planning for the future, and individually able to choose and make the right decisions in developing those potentials. Group guidance is more efficient because it can serve many individuals in a shorter time (Corey, 2015; Neukrug, 2012). Today, groups are used by many counselors and are an important and often used intervention method that rivals the existence of individual and family counseling (Neukrug, 2011). The use of group formats is seen as a strategy for providing excellent guidance and counseling to discuss interpersonal and intrapersonal issues, facilitate positive development, and learn new information and skills (Neukrug, 2011; Toseland \& Rivas, 2017).

The implementation and results of group guidance activities are influenced by two primary components, namely the counselor and group members (Hartinah, 2009; Prayitno, 2017). It directly relates the characteristics and roles of these two components are directly to the development of group dynamics. Group dynamics is a variable that moves, changes, individual and group which includes the level of participation, barriers, communication patterns, relationships between members and between members and leaders, nonverbal behavior, moods, and feelings that arise and /or expressed (Brown, 2004). Group dynamics refers to interactions and interrelations between group members that are ongoing and between leaders and group members (Gladding, 2003). This interaction is a function of the power of the conscious and unconscious and is influenced by various things such as group structure, the theoretical orientation of leaders, the unique personality of leaders and members, the motivation of leaders and members, and a myriad of other influences (Neukrug, 2011).

Motivation is an important aspect that must be owned by students (Hariko, 2018) who are believed to have a positive effect on social interaction of individuals in the group, mental condition and the expected results of group guidance activities. The motivation of prospective group member students is an important aspect that should be the counselor's main consideration in planning group guidance activities. Some experts put forward a general definition of motivation based on theoretical background. In general, psychologists define motivation as a psychological process concerned with direction, enthusiasm, and persistence or persistence of behaviour (Moreno, 2010; Nolen-Hoeksema et al., 2014). Motivation is a process in which activities directed at goals are provoked and sustained, involve 'goals' that provide encouragement and direction for action, and require physical and mental activity (Schunk et al., 2012; Schunk \& DiBenedetto, 2020). Motivation is an impulse in a person which is indicated by the existence of desires and interests, encouragement and needs, and hopes (Uno, 2007). Motivation is a unifying term for various groups of phenomena and constructs that are all related to regulating behavior directed at the goal (Schultheiss et al., 2012).

The current study specifically examines student motivation in terms of three aspects, namely the desire or desire to follow group guidance, and expectations for the results of group guidance activities. Here, the aspects of motivation studied are a combination, each of which contains intrinsic and extrinsic elements of motivation. Although traditionally intrinsic and extrinsic motivation are considered mutually exclusive, a more 
contemporary view holds that both can act simultaneously (Moreno, 2010). It defines intrinsic motivation as motivation to engage in learning activities for the benefit of the individual himself, while extrinsic motivation is defined as motivation to engage in an activity to an end (Schultheiss et al., 2012; Schunk et al., 2012).

The research findings reveal that students' motivation to attend group guidance is high, both highlighted based on overall data and each aspect. The finding on the first aspect is that most students have a chief desire to follow group guidance. Students report acute attention and interest and positive responses to group guidance activities. It can be stated that attention is related to motivation. Research conducted by Di Bello, Giamundo, Brunamonti, Cirillo, \& Ferraina (2019) present evidence for this, where they find that attention and motivation interact exclusively, especially for spatial attention. Similarly, research conducted by Wilhelm, Miller, \& Gable (2019) concluded that motivation is related to among them the scope of attention, where the narrowing of attention resulting from an increase in motivational status can improve performance and learning.

Attention is an individual's activity in relation to the selection of stimuli that come from his environment (Slameto, 2010) and is one of the psychological requirements for perception (Walgito, 2010) namely the cognitive process of organizing, interpreting and interpreting the stimulus received by the individual through the sense media (Moreno, 2010; Nolen-Hoeksema et al., 2014). Related to current research, the stimulus that is the focus of students' attention is information about the general picture, ways to follow and schedule group guidance activities. Students who are highly motivated to take group guidance in writing a report that they focus to the general description of group guidance explained by the counselor, ask questions about ways to take part in activities, and try to find out schedules for him to take part in activities. The stimulus in the form of information is periodically conveyed by the counselor in class meetings, especially at the beginning of the start of the school year.

Students' willingness to attend group guidance is also measured based on their interest in the activity. This indicator is a continuation or product of the process of attention and perception. Moreno (2010) pointed out that students who have a high motivation to study a topic diligently because he felt it was interesting. Various interesting things about group guidance activities can be stated in this discussion. Factual topics (Brown, 2004; Prayitno, 2017), a sense of community that shows students that they are part of a social system where there is hope to create an unorthodox life (Corey et al., 2014), opportunities to practice newly learned behaviors in a trusted environment, an atmosphere where members support one another (Neukrug, 2011) are some of the potential aspects that are of interest to students. Interest in these aspects is at the same time related to students' responses to group guidance. High attention and interest are predicted to be the reason students have positive responses to group guidance.

A review of the data on the second aspect presents the conclusion that students have a high incentive to follow group guidance. Students have a prime motivation to get to know and understand, involve themselves in and discuss factual topics in group guidance activities. Encouragement in students is one of the fundamental aspects that can influence their motivation to follow group guidance. Encouragement is a condition that arises because of the presence of several needs (Nolen-Hoeksema et al., 2014). Meanwhile, a state of an impulse in an individual is interpreted as readiness to move due to needs, for example physical needs, and needs that arise because of environmental conditions or mental states (Walgito, 2010).

Some theories about motivation talk about needs as one of the most important motivational aspects. The humanistic theory of motivation specifically places motivation for each activity into a hierarchy of needs (Moreno, 2010). As one of the main figures in the development of humanistic psychology, Maslow put forward the concept of a hierarchy of human needs ranging from basic biological needs to more complex psychological needs (Nolen-Hoeksema et al., 2014; Schunk et al., 2012). The primary emphasis of Maslow's motivational theory is on the hierarchical system, where needs at a level must be at least partially met before needs at the next level become determinants of individual action.

Group guidance is seen as one service that is really needed by every student. The existence of services and group guidance specifically aims to meet students' needs in relation to self-development. Group guidance is a very effective medium for facilitating life transitions, achieving developmental tasks, addressing specific needs, preparing for participation in community and community life, helping to protect the potential of students, and developing social relationships and emotional ties (Brown, 2004; Gladding, 2012). These aspects reflect the students' need for security to the highest level, namely self-actualization. It should also be underlined that feeling of security is the prime condition needed for the development of students' self-motivation (Moreno, 2010) which usually grows based on perceptions of counselors and activities. These needs have a direct effect on students' drive to get to know and understand, involve themselves in activities and discuss topics needed in group guidance. Aspects as expressed are indicators of student motivation assessment following group guidance in this study. 
Analysis of the last aspect also shows data consistent with the findings of the two previous indicators. Most students have very high expectations for the potential results of group guidance. According Schunk (2012) hope is a personal belief about the outcome of the anticipated action. Expectations are an important aspect of motivation that is closely related to goals. Along with the objectives, expectation is an aspect which is an important mechanism in social cognitive theory (Schunk., 2012; Schunk et al., 2012) and the theory of expectation value (Moreno, 2010). In the view of social cognitive theory, motivation is behavior directed at the goals that are provoked and defended by the expectations of individuals regarding the expected results of their actions and their self-efficacy to carry out those actions (Schunk, 2012). Meanwhile, the expectation value theory holds that students' motivation to engage in an action is a product of two main forces, namely the expectation to achieve goals and the value of goals (Moreno, 2010). Based on this view, if students' expectations to achieve the goals of group guidance activities are low, they are not motivated to participate in these activities.

It focuses expectations on the results on general and specific group guidance goals that refer to the areas of personal, social, learning and career development. The current results of the study present concrete evidence of students' high expectations of the potential results of group guidance. Students really hope that through group guidance, insights, knowledge, new skills, a proper understanding of values and optimal selfdevelopment in the fields of personal, social, learning and career life will be prevented from various potential obstacles and problems. These hopes and goals refer to the major function of group guidance services, namely the function of understanding and development (Hartinah, 2009; Prayitno, 2017). Through group it provides guidance students to improve self-understanding, encourage personal growth and empowerment, and prevent future problems through dissemination of mental health education in groups (ASGW, 2000; Brown, 2011; Gladding, 2003; Neukrug, 2012).

Comparative testing of students' motivation to follow group guidance in the current study presents evidence that there are significant differences in the two types of gender. The difference in the mean scores of students 'motivation scores of both genders shows that male students' motivation is lower than that of girls. These findings provide recent evidence about the motivation of prospective group members before they follow group guidance. So far, there have been many comparative descriptive and descriptive studies based on gender differences or other aspects that measure student motivation towards learning activities (E.g Edli \& Mudjiran, 2015; Hidayat, Nirwana, \& Syahniar, 2016) or motivation of students towards certain fields of study or learning activities (E.g, Tasiwan, Nugroho, \& Hartono, 2014). Unfortunately, very few research publications have been found about students' motivation to follow group guidance that measures conditions before activities. Interestingly, even though the numbers are tiny, even almost hard to find, group guidance is widely used as a treatment medium to increase motivation for certain aspects of the experimental model research (E.g, Neviyarni \& Irianto, 2016).

Research on gender-based differences on motivation or other psychological aspects is very important to do. Some basic reasons for this, namely: the large stereotype of psychological gender differences that affect society so it needs to be evaluated accurately based on scientific evidence, psychological gender differences are often related or influence on policies to form one gender or different groups (Hyde, 2014). Associated with group guidance activities, the current data is very useful for counselor policies in selecting, recruiting and determining group composition. For example, the results of research showing differences in motivation between the two genders in current research can be used as an important basis for counselors in determining group composition. Counselors can more freely consider whether to form homogeneous groups with one gender, heterogeneous groups with balanced comparisons for both types of gender or heterogeneous groups with more numbers in one gender.

Reviewing psychological gender differences has fascinated experts and encouraged them to engage in a lively debate (Hyde, 2014). During adolescence, women and men experience important changes related to gender that can shape motivation, self-concept, beliefs, goals and social relationships (Daniels \& Leaper, 2011). In particular, gender differences in forming motivation have an extensive history in psychology and education research (Meece et al., 2006). In mainstream educational psychology, gender differences in motivation and attitudes have long been explored in an effort to explain gender differences in attainment and career choices in certain fields of study (Mori \& Gobel, 2006). Women's motivation and academic involvement is higher in than men (Martin, 2012). Although women's motivation is superior, men have a higher motivation in mathematics and sports, and women have a higher motivation in verbal, writing, reading and language tasks (Mori \& Gobel, 2006; Pahlke \& Goble, 2015).

The diversity of motivations and other psychological aspects of students as the effect of gender differences is hypothesized to originate from the influence of various factors. The combination of cultural, interpersonal, cognitive motivational, biological, socio-emotional skills, socialization, gender stereotypes and interests influences many genders-related issues facing immature people during adolescence (Daniels \& Leaper, 2011; Pahlke \& Goble, 2015). Socialization experiences and achievements play an important role in the development 
of gender differences in motivation (Meece et al., 2006). Socialization in the home environment as the first environment plays a very urgent role in shaping students' gender beliefs and behavior. Students validate, improve, apply and verify it in the school environment and the wider sociocultural environment.

The socialization that took place in the social environment, with all the cultural diversity that includes ethnicity, religion, race and socioeconomic status in the shape shaping students' social identity based on gender. Some research findings as summarized Mori \& Gobel (2006) dan Pahlke \& Goble (2015) prove that women are more likely to be motivated on literacy tasks, such as: verbal tasks, writing, reading and language, allegedly to be the reason they are more motivated to follow group guidance. Based on a review of gender stereotypes and interests, several sources of study and school activities are identified with the social identity of one gender. This prototype contributes to students' interests and ultimately motivation. Scientific research is needed to prove these allegations. However, the principal point to keep in mind regarding the current research results is that although female gender is superior, the motivation for both types of gender is high.

The current discussion does not elaborate on the findings related to students' motivation to attend group guidance based on ethnic differences. This decision was taken with the consideration that there is no difference in motivation to attend group guidance for students from different ethnic backgrounds. The most plausible reason for this finding is due to the uneven distribution of data from each ethnic group. It can be clearly seen that students from the Minang - one of type of ethnic group in Indonesia that adheres to the matrilineal inheritance tradition system and matrilocal residency called matriarchate which administratively occupies the territory of West Sumatra Province, and spreads throughout Indonesia, Malaysia and a number of other countries as nomads (Hadler, 2013; Hariko et al., 2021; Melalatoa, 1995) - ethnic group dominate the research population. Future research requires a more representative population for each ethnicity to prove there are or -not a significant difference

Based on the research findings can be put forward suggestions about the direction of research. Research related to students 'motivation to follow this group guidance needs to be replicated by involving a sample of students in different research areas, and research on the description of students' motivation to follow other types of services. Given the prime motivation of students, the next researcher needs to conduct research to collect data about the implementation or implementing group guidance in schools. Current research findings are expected to be followed up by the counselor by increasing the frequency of implementing group guidance. Then, current research does not explicitly separate the intrinsic and extrinsic aspects of motivation. Although contemporary views argue that both can act simultaneously, future research is expected to use a measuring instrument that distinguishes the two so that data about the motivation that are more dominant in students are obtained.

\section{Conclusion}

Group guidance is a guidance and counseling service organized by a counselor to several students to discuss factual topics in a group format by utilizing group dynamics. Theoretically, this service is a very effective forum for developing positive aspects of development and prevention of negative aspects of student development. The current research aims to describe the motivation of students to follow group guidance and examine differences in student motivation to follow group guidance based on gender and ethnicity. Student motivation is assessed based on several indicators, including: desire and interest to follow group guidance, encouragement and the need to follow group guidance, as well as expectations of the potential results to be obtained from group guidance activities. The results of data analysis show that most students have high motivation to follow group guidance. Related to testing differences it was concluded that there were significant differences in students' motivation to attend group guidance based on gender. Meanwhile, in terms of ethnicity did not show significant differences. Specifically, the data revealed that male students' motivation to attend group guidance was lower than female students. Based on these findings, school counselors should consider heterogeneity and/or gender homogeneity in group formation for the implementation of group guidance, in accordance with the goals and objectives to be pursued.

\section{References}

Association for Specialists in Group Work. (2000). Professional Standards for the Training of Group Workers. The Journal for Specialists in Group Work, 25(4), 327-342. https://doi.org/10.1080/01933920008411677

Astuti, A. D. (2019). Pengaruh Layanan Bimbingan Kelompok dengan Metode Pemberian Tugas terhadap Kesulitan Belajar Siswa Kelas X Sekolah Menengah Atas Negeri 1 Galur Tahun Pelajaran 2018/2019. GCouns: Jurnal Bimbingan Dan Konseling, 3(2).

Brown, N. W. (2004). Psychoeducational Groups: Process and Practice. Brunner-Routledge. Corey, G. (2015). Theory and Practice of Counseling and Psychotherapy. Nelson Education. 
Corey, M. S., Corey, G., \& Corey, C. (2014). Groups: Process and Practice(9th ed.). Cengage Learning.

Daharnis, D., Erlamsyah, E., Ifdil, I., Ardi, Z., \& Hariko, R. (2014). Gambaran Kegiatan Belajar Siswa Sumatera Barat.

Daniels, E. A., \& Leaper, C. (2011). Gender Issues. In Encyclopedia of Adolescence (pp. 151-159). https://doi.org/10.1016/B978-0-12-373951-3.00017-X

Di Bello, F., Giamundo, M., Brunamonti, E., Cirillo, R., \& Ferraina, S. (2019). The Puzzling Relationship between Attention and Motivation: Do Motor Biases Matter? Neuroscience, 406, 150-158.

Edli, H., \& Mudjiran, M. (2015). Perbedaan Motivasi dan Keterampilan Belajar Peserta Didik Berprestasi Tinggi dan Rendah Serta Implikasi dalam Bimbingan dan Konseling. Konselor, 4(1), 26-32.

Fatmala, I., \& Nursalim, M. (2019). Bimbingan Kelompok Teknik Diskusi untuk Meningkatkan Pemahaman Perilaku Bullying Siswa Kelas VIII SMPN 2 Gedangan. Jurnal BK UNESA, 101).

Gladding, S. T. (2003). Group Work: A Counseling Specialty (7th ed.). Prentice-Hall.

Gladding, S. T. (2012). Counseling: A Comprehensive Profession. Pearson Higher Ed.

Hadler, J. (2013). Muslims and matriarchs: Cultural resilience in Indonesia through jihad and colonialism. Cornell University Press.

Hariko, R. (2016). Ilmu Bimbingan dan Konseling, Nilai dan Kesejahteraan Individu: Studi Literatur. Jurnal Konseling Dan Pendidikan, 4(2), 118-123.

Hariko, R. (2017). Landasan Filosofis Keterampilan Komunikasi Konseling. Jurnal Kajian Bimbingan Dan Konseling, 2(1). https://doi.org/10.17977/um001v2i22017p041

Hariko, R. (2018). Are High School Students Motivated to Attend Counseling? COUNS-EDU: The International Journal of Counseling and Education, 3(1). https://doi.org/10.23916/0020180312210

Hariko, R. (2020). Pengembangan Model Bimbingan Kelompok Agentik untuk Meningkatkan Perilaku Prososial Siswa Sekolah Menengah Pertama. Universitas Negeri Malang.

Hariko, R. (2021). Bimbingan Kelompok Agentik: Model Peningkatan Perilaku Prososial Siswa. CV. Literasi Nusantara Abadi.

Hariko, R., Hanurawan, F., Lasan, B. B., \& Ramli, M. (2021). Dimensionality of Prosocial Tendencies on Minangkabau Early Adolescents. International Journal of Learning and Change, 13(1), 34-48. https://doi.org/10.1504/IJLC.2021.10027066

Hariko, R., \& Ifdil, I. (2017). Analisis Kritik Terhadap Model Kipas; Konseling Intensif Progresif Adaptif Struktur. Jurnal Konseling Dan Pendidikan, 5(2), 109-117.

Hartinah, S. (2009). Konsep Dasar Bimbingan Kelompok. PT. Refika Aditama.

Hidayat, H., Nirwana, H., \& Syahniar, S. (2016). Perbedaan Motivasi Belajar, Mutu Keterampilan Belajar, dan Self Regulated Learning Siswa Kelas Diklat dan Siswa Kelas Reguler. Konselor, 5(1), 33-41.

Hyde, J. S. (2014). Gender similarities and differences. Annual Review of Psychology, 65, 373-398.

Ifdil, I., Hariko, R., Bariyyah, K., Zola, N., \& Amalianita, B. (2020). Evaluation of the understanding of School Counselors on Individual Counseling Process in Indonesia. TEST Engineering \& Management, 83, 1035210356.

Martin, A. J. (2012). High School Motivation and Engagement: Gender and Age Effects. Online Submission.

Meece, J. L., Glienke, B. B., \& Burg, S. (2006). Gender and motivation. Journal of School Psychology, 44(5), $351-$ 373.

Melalatoa, M. J. (1995). Ensiklopedi Suku Bangsa di Indonesia Jilid LZ. Direktorat Jenderal Kebudayaan.

Moreno, R. (2010). Educational Psychology. John Wiley \& Sons, Inc.

Mori, S., \& Gobel, P. (2006). Motivation and gender in the Japanese EFL classroom. System, 34(2), 194-210.

Nengsih, N. (2019). Pengaruh Layanan Bimbingan Kelompok Terhadap Perencanaan Arah Karier Siswa SMA Pembangunan Laboratorium Universitas Negeri Padang. AL-IRSYAD, 71 ).

Neukrug, E. (2011). The World of The Counselor: An Introduction to The Counseling Profession. Nelson Education.

Neviyarni, N., \& Irianto, A. (2016). Efektivitas Layanan Bimbingan Kelompok untuk Meningkatkan Motivasi Belajar dan Mengurangi Perilaku Membolos Siswa. Konselor, 3(4), 180-195.

Nolen-Hoeksema, S., Fredrickson, B., Loftus, G. R., \& Lutz, C. (2014). Atkinson \& Hilgard's Introduction to Psychology. Cengage Learning EMEA.

Normanita, R. W., Kurniawan, K., \& Nusantoro, E. (2018). Meningkatkan interaksi sosial dengan teman sebaya melalui layanan bimbingan kelompok dengan teknik cinematherapy. Indonesian Journal of Guidance and Counseling: Theory and Application, 73$), 1-7$.

Pahlke, E., \& Goble, P. (2015). Gender and Education. In International Encyclopedia of the Social \& Behavioral Sciences (pp. 682-688). https://doi.org/Pahlke, E., \& Goble, P. (2015). Gender and Education. International Encyclope10.1016/b978-0-08-097086-8.92151-2

Prayitno. (2017). Konseling Profesional yang Berhasil. PT. Rajagrafindo Persada.

Putra, S. (2019). Efektifitas Layanan Bimbingan Kelompok untuk Meningkatkan Sikap Kedisiplinan Siswa. Jurnal Penelitian Pendidikan Sosial Humaniora, 41), 493-500.

Schultheiss, O. C., Strasser, A., Rosch, A. G., Kordik, A., \& Graham, S. C. C. (2012). Motivation. In Encyclopedia of 
Human Behavior (pp. 650-656). https://doi.org/10.1016/B978-0-12-375000-6.00238-X

Schunk., D. H. (2012). Learning Theories : An Educational Perspective(6th ed.). Allyn \& Bacoon, Inc.

Schunk, D. H., \& DiBenedetto, M. K. (2020). Motivation and social cognitive theory. Contemporary Educational Psychology, 60, 101832.

Schunk, D. H., Meece, J. R., \& Pintrich, P. R. (2012). Motivation in education: Theory, research, and applications. Pearson Higher Ed.

Slameto. (2010). Belajar dan Faktor yang Mempengaruhinya. Rineka Cipta.

Tasiwan, T., Nugroho, S. E., \& Hartono, H. (2014). Analisis Tingkat Motivasi Siswa Dalam Pembelajaran IPA Model Advance Organizer Berbasis Proyek. Jurnal Pendidikan IPA Indonesia, 3(1).

Toseland, R. W., \& Rivas, R. F. (2017). An Introduction to Group Work Practice(8th ed.). Macmillan.

Uno, H. B. (2007). Teori Motivasi \& Pengukurannya. Bumi Aksara.

Walgito, B. (2010). Pengantar Psikologi Umum. CV. Andi Offset.

Wilhelm, R. A., Miller, M. W., \& Gable, P. A. (2019). Neural and Attentional Correlates of Intrinsic Motivation Resulting from Social Performance Expectancy. Neuroscience, 416, 137-146. 